\title{
ROSE POGONIA - AN ORCHID NEW O MANITOBA
}

\author{
ETER TAYLOR, P.O. Box 597, Pinawa, Manitoba. ROE 1 LO
}

Several eastern North American chids approach their western limits of stribution in the boreal forest of utheastern Manitoba. ${ }^{67}$ The Rose ggonia (Pogonia ophioglossoides (L.) er.) is a showy pink-flowered species hich has apparently not been reported eviously from Manitoba, but has been corded as far northwest as the Rainy ver district of northwestern Ontario, adjacent northeastern nnesota. ${ }^{85}$ This prompted me to ok for this species while exploring me bogs in southeastern Manitoba.

On 1 August 1982 I visited an open $\mathrm{g}$ within the Bog River wetland comex, approximatley $6 \mathrm{~km}$ southeast of ver Hills, Manitoba $\left(50^{\circ} 2^{\prime} \mathrm{N}, 95^{\circ} 57^{\prime}\right.$ ), and was delighted to find 15 Rose gonia plants in bloom. These includone group of 10 plants within an area about one square metre. All were owing in an extensive stand of sedges arex spp.) and small birch shrubs etula glandulifera), with scattered eds (Phragmites communis) and hall tamarack trees (Larix laricina), d numerous Pitcher Plants arracenia purpurea).

All the Pogonia plants were growing png a $300 \mathrm{~m}$ stretch of a north - south tline, which is lightly used by snowbiles in winter. The sedges were orter, and the ground was wetter, on trail than off it. Brief off-trail searches not reveal any more Pogonias. Case tes "[Rose Pogonia] usually grows the wettest parts of the bog, often on ating tufts of sedge.... If present at it is usually abundant. It spreads by ans of root shoots and forms dense lonies."
No Pogonia specimens were collected, but satisfactory photographs of two blooms were obtained and accompany this article. Colour photographs and a detailed map of the locality have been deposited with the Manitoba Museum of Man and Nature, Winnipeg, and the herbarium of the Whiteshell Nuclear Research Establishment, Pinawa.

Two similarly coloured orchids occur in bogs in southeastern Manitoba: Arethusa, Dragon's Mouth or Swamp Pink (Arethusa bulbosa) and Calopogon or Grass Pink (Calopogon pulchellus). ${ }^{34}$ Arethusa resembles Rose Pogonia, but has a much more slender leaf and less prominent floral bract; the bloom is a more purplish pink and lacks the fringing of the lip. Calopogon is readily distinguished by the "inverted" configuration of the bloom, with the narrow lip uppermost. It also normally has more than one flower per stem, whereas the Pogonia usually has only a single flower. Case notes "Arethusa, Rose Pogonia and Calopogon regularly occur together. Rarely indeed in northern Michigan or Wisconsin does one of these species occur without the other two; yet at times each does grow where the other two do not." In southeastern Manitoba I have found Arethusa and Calopogon in partly open black spruce - tamarack bogs, including an area within $1 \mathrm{~km}$ of the Rose Pogonia locality. However, neither appears to be present where the Pogonias were found. Two other orchid species were found growing near the Pogonias: Hooded Ladies' Tresses (Spiranthes romanzoffiana) and White Bog Orchid (Habenaria dilatata). 


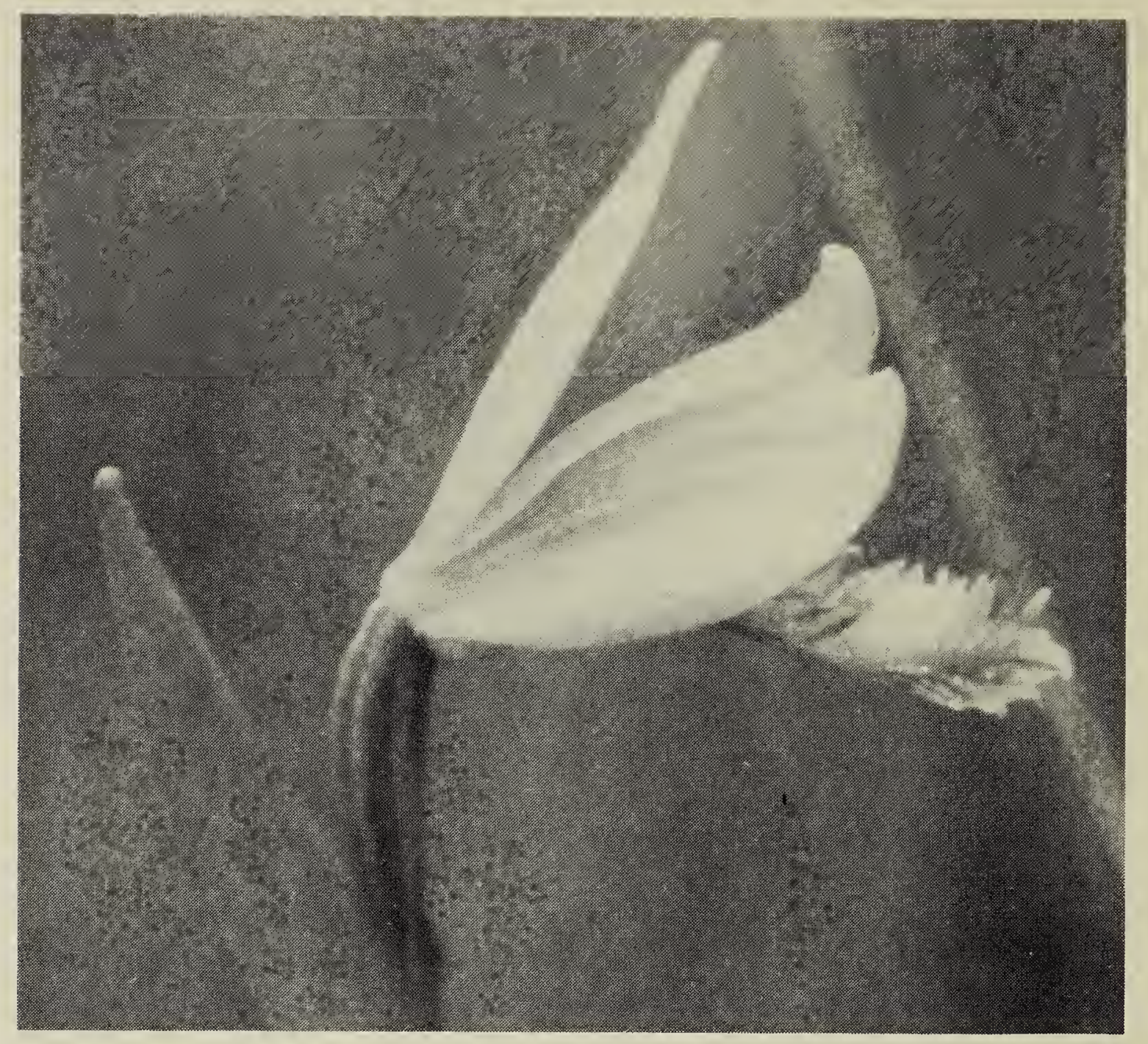

Rose Pogonia near River Hills, Manitoba

Peter Taylor

It is interesting that Arethusa occurs locally along a narrow band from southeastern Manitoba to northwestern Saskatchewan, while Calopogon and Rose Pogonia appear to reach their range limits in southeastern Manitoba. ${ }^{4} 367$ The latter two orchids bloom later than Arethusa in southeastern Manitoba, and it may well be worth searching for them in appropriate habitats farther northwest, in July or early August.

\section{Acknowledgement}

I am grateful to Janet R. Dugle for teaching me to look at the ground occasionally while birding, and for helpful suggestions on this article.

'CASE, F.W., Jr. 1964. Orchids of the Western Great Lakes Region. Cranbrook Institute of Science.
${ }^{2}$ HARMS, V. L., C. A. KINDRACHUK an B. C. GODWIN, 1977. Further Record of the Rare Dragon's Mouth (Swam Pink) Orchid, in Saskatchewan. Bli Jay 35: 138-141.

${ }^{3}$ JOHNSON, K., 1981. Rare Plant Aler Orchid Gives Bees Plenty of Spills ar Thrills. Bull. Man. Nat. Soc. 4(6): 7.

${ }^{4}$ JOHNSON, K., 1981. Rare Orchids Part I Arethusa: The Dragon's Mouth Orchic Bull. Man. Nat. Soc. 4(7): 7.

${ }^{5}$ LAKELA, O., 1965. A Flora of Northeaster Minnesota. Univ. of Minnesota Pres: Minneapolis.

${ }^{6}$ LOOMAN, J. and K. F. BEST, 1979. Budd Flora of the Canadian Prairie Province Agriculture Canada Pub. 1662.

'SCOGGAN, H. J., 1957. Flora of Manitob Natl. Mus. Can. Bull. No. 140.

${ }^{8}$ SCOGGAN, H. J., 1978. The Flora Canada, Part 2 - Pteridophyta, Gym nospermae and Monocotyledoneat Natl. Mus. Nat. Sci., Ottawa. 